Bryn Mawr College

Scholarship, Research, and Creative Work at Bryn Mawr College

2014

\title{
Learning About Being a Scientist from the Vitamin B-12 Structure Collaboration
}

Susan White

Bryn Mawr College, swhite@brynmawr.edu

Let us know how access to this document benefits you.

Follow this and additional works at: http://repository.brynmawr.edu/chem_pubs

Part of the Chemistry Commons

\section{Custom Citation}

S. A. White, "Learning About Being a Scientist from the Vitamin B-12 Structure Collaboration," Biochemistry and Molecular Biology Education 42.6 (2014): 507-509.

This paper is posted at Scholarship, Research, and Creative Work at Bryn Mawr College. http://repository.brynmawr.edu/chem_pubs/13

For more information, please contact repository@brynmawr.edu. 


\section{Historical Review}

Learning About Being a scientist from the

Susan A. White ${ }^{*}+$

\section{Vitamin B 12 Structure Collaboration}

From the ${ }^{\dagger}$ Department of Chemistry, Bryn Mawr College, Bryn Mawr,

Pennsylvania 19010

\section{Abstract}

This historical note reviews the work that resulted in the publication of the structure of Vitamin $\mathrm{B}_{12}$. The collaborations and resulting friendships that developed during this time made a strong impression on the author and encour- aged her to pursue a scientific career. (c) 2014 by The International Union of Biochemistry and Molecular Biology, 00(0):000-000, 2014.
Keywords: vitamin $B_{12} ;$ cobalamin; undergraduate teaching; scientific collaboration; mentoring

\section{Introduction}

It is the end of another academic term and inevitably several chemistry majors have sent me e-mails requesting letters of recommendation for medical school. They visit my office armed with their resumés and personal statements that amplify their love for science and their desire to work with people. Some are almost apologetic "it's not that I don't love science" or disappointed that I don't "get” that the only possible career for a "people person" scientist is medicine.

Many such exchanges over the years have caused me to examine my own career choice. What was it about science and research appealed to me? Unlike many of my students, I had a scientist father and had many indelible childhood impressions about doing science. Growing up, I learned that scientists 1) make lifelong friendships that are renewed via letters and travel to meetings and visits and 2) tackle a compelling problem over a long period of time. In this essay, I will discuss my observations and recollections of my father, John G. White in Princeton, NJ, and his collaborator, Dorothy C. Hodgkin in Oxford, UK, and their endeavor to determine the three-dimensional structure of Vitamin $B_{12}$ in the 1950s [1]. Vitamin $B_{12}$, or cyanocobala-

\footnotetext{
*Address for correspondence to: Susan A. White, Department of Chemistry, Bryn Mawr College, 101 N. Merion Ave., Bryn Mawr, Pennsylvania 19010, USA. E-mail: swhite@brynmawr.edu

Received 16 July 2014; Accepted 2 September 2014

DOI 10.1002/bmb.20828

Published online 00 Month 2014 in Wiley Online Library

(wileyonlinelibrary.com)
}

min, is found in raw liver and was discovered to be the cure for pernicious anemia in 1948 [2].

At this time, crystallographic computing was in its infancy, visualization tools were unknown, and with 93 nonhydrogen atoms, complete structure determination was an ambitious undertaking. Success in structure determination of a molecule this large might provide encouragement that protein structures could be solved [3, 4]. Cyanocobalamin has an elegant structure with the central cobalt ion octahedrally coordinated to four nitrogen pyrroles in a corrin ring, a nucleotide, and a cyanide group (Figure 1). At the outset of the research, not all of the chemical constituents or how they bonded were known, thus analytical methods and degradation products were used to strengthen the crystallographic conclusions. The authors eloquently stated this point in their 1955 article: "To be able to write down a chemical structure very largely from purely crystallographic evidence on the arrangement of atoms in space-and the chemical structure of a quite formidably large molecule at that-is for any crystallographer something of a dream-like situation” [1].

The first lesson that I learned was that science is collaborative and that there was, even in pre-Facebook days, an abundance of communication, although on a much slower time scale. In my younger years, blue aerogramme letters arrived from exotic locations, and I learned that both men and women were part of the international scientific enterprise. They discussed details of crystal forms, refinements, and missing atoms mixed with the news about new babies and houses. The core group of collaborators continued to send letters and family photos for decades. My dad's returns from conferences were happy occasions at which meetings with friends and collaborators were recounted. I was especially impressed at the special bond 


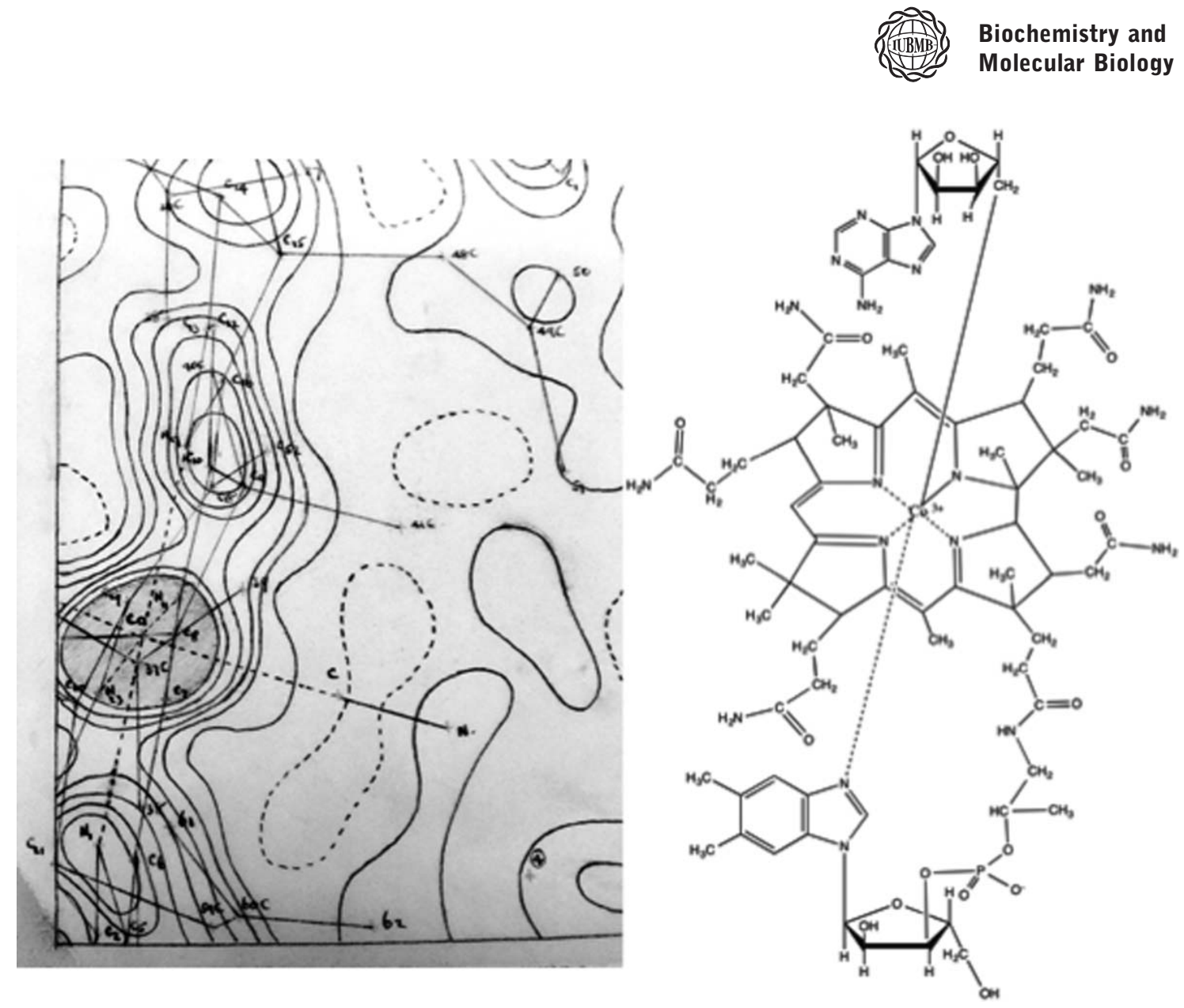

FIG 1

Partial hand-drawn tracing of electron density map of vitamin $B_{12}$ that contains Co(III) in the lower left and vitamin $B_{12}$ structure.

that existed between a professor and early graduate students. News of Hodgkin's 1964 Nobel Prize was announced in our house by a very exciting early morning flurry of telegrams.

For me, the supremely social aspect of science was one of my first observations of the adult world. When I met the Hodgkin family in my early 20s, I was impressed at their graceful hospitality and cosmopolitan interests. As I progressed through graduate and postdoctoral training to my current position, I too was delighted to form these strong associations with colleagues, professors, and students. Being part of a research group, and later creating my own research group, has been one of my most satisfying activities for scientific, pedagogical, and social reasons.

The second lesson I learned observing my father was that doing science requires persistence, single-minded solitary hard work, and a belief in the importance of the research problem. I often saw my dad doing rapid sliderule calculations, going through stacks of computer printouts, or visualizing hand-drawn electron density maps with corkboard, wire, and wax ball models. Ironically, Hodgkin was initially optimistic that the structure of vitamin $B_{12}$ would soon be in hand as the cobalt position was visible by
1950, yet the full structure was not published until 1955 [3]. Although some of my students may find this to be an impossibly long period of time to be immersed in one problem, I find it to be an intellectual necessity, one that is a worthy pursuit requiring the reworking of existing strategies, use of new technologies, and development of interdisciplinary collaborations. In the Vitamin $\mathrm{B}_{12}$ research, assistance in structure calculations that produced the partial structure published in 1954 was given by four women using tabulating machines, whereas the article published in 1956 acknowledges help from two men and two women using an electronic computer [5, 6]. Indeed, due, in part, to this risky effort by researchers on both sides of the Atlantic, X-ray crystallography has been used to solve just more than 90,000 macromolecular structures [7], and we are now in the midst of a celebration "2014 International Year of Crystallography" (www.iycr2014.org/).

Years later, through decades-old letters from Hodgkin and others, I learned some hard scientific realities concerning the delicate negotiations required to transition from unintentional competition to collaboration (personal correspondence, D. C. Hodgkin to J. G. White, October 4, 1950; Bodleian Library, University of Oxford). Fortunately, 
advancing science and fairly apportioning authorship seem to have been the driving forces in the Vitamin $\mathrm{B}_{12}$ collaboration (personal correspondence, D. C. Hodgkin to J. G. White, August 7, 1955 and November 13, 1958; Bodleian Library, University of Oxford). Throughout my career, I have found participation in long-term research projects, with the inevitable ebb and flow of activities and successes, to be both stimulating and satisfying, and yes, seeing a macromolecular structure for the first time after completing years of biochemical experiments was a "dream-like situation” for me.

The challenge that we face today is in communicating the special nature of the scientific community and the workings of research groups to all of our young students. We need robust, real-world research programs that welcome neophyte researchers so that students can "test drive" the life of a researcher. However, we also need to be tolerant of students who select medicine and other professions despite our best efforts to introduce them to life in the laboratory. Perhaps they will fondly remember their days at the research bench and apply their personal knowl- edge of the scientific community to funding decisions or public policy debates.

\section{References}

[1] Hodgkin, D. C., Pickworth, J., Robertson, J. H., Trueblood, K. N., Prosen, R. J., and White, J. G. (1955) The crystal structure of the hexacarboxylic acid derived from $B_{12}$ and the molecular structure of the vitamin. Nature $178,325-328$.

[2] Chanarin, I. (2000) A history of pernicious anemia. Br. J. Haematol. 111, 407-415.

[3] Ferry, G. (1998) Dorothy Hodgkin: A Life, Granta Books, London, pp. 248-285.

[4] White, J. G. (1962) The structure of vitamin $B_{12}$. III. The crystal structure analysis of the air-dried $B_{12}$ crystals. Proc. R. Soc. A 266, 440-464.

[5] Brink, C., Hodgkin, D. C., Lindsey, J., Pickworth, J., Robertson, J. H., and White, J. G. (1954) X-ray crystallographic evidence on the structure of vitamin $\mathrm{B}_{12}$. Nature 174, 1169-1171.

[6] Hodgkin, D. C., Kamper, J., Mackay, M., Pickworth, J., Trueblood, K. N., and White, J. G. (1956) Structure of vitamin $B_{12}$. Nature 178, 6467.

[7] Berman, H. M., Westbrook, J., Feng, Z., Gilliland, G., Bhat, T. N., Weissig, H., Shindyalov, P. and Bourne, P. E. (2000) The Protein Databank, Nucleic Acids Research, 28, 235-242. www.pdb.org. 